\title{
Comparative Pharmacognostical Evaluation of Three Market Samples of Kharjura (Phoenix Dactylifera Linn.)
}

\author{
Research Article
}

\section{Sujata P Dhoke ${ }^{1 *}$, Harisha CR $^{2}$, Prashant Shinde ${ }^{3}$, Murali Krishna C ${ }^{1}$, Babu G}

1. Research Officer, Regional Ayurveda Research institute for skin disorders, Vijayawada

2. Head, Pharmacognosy Department, IPGT \& RA, Jamnagar, Gujarat, India

3. Research Officer, Regional Ayurveda Research institute for Nutritional disorders, Mandi

4. Assistant Director In-charge, Regional Ayurveda Research institute for skin disorders, Vijayawada.

\begin{abstract}
Kharjura(Phoenix dactylifera Linn.) fruits (Kharjura) are widely used by the traditional medical practitioners for the treatment of various diseases in their daily practices. According to Ayurvedic principles, the kharjura fruit Phoenix dactylifera Linn.is sweet (Madhura Rasa) in taste and increase moistness of tissues and balance Pitta and Vata Dosha (humours of body).Its fruits are used in various diseases like Kshaya (Malnutrition), Daha (Burning Sensation), Raktapitta (blood disorders), Murchha (Syncope), Trishna (Thirst), Shrama(exhaustion), Jwara (fever), Swasa (respiratory disorders), Kasa (cough), Madatyaya (Alcoholism) etc. Present study highlights pharmacognostical difference between varieties of two fresh fruits of Kharjura and one variety of Dry Kharjura. The results revealed that the fresh Kharjura variety contains presence of groups of stone cell, lignified stone cells layer, mesocarp cells, cells of parenchyma with starch grains, and dry Kharjura variety contain saccharine contents while silica deposition, starch grains, vascular bundle after stain with xylem.
\end{abstract}

Keywords: Dry Kharjura, Red Kharjura, Starch grains, Yellow Kharjura.

\section{Introduction}

Kharjura fruit of Aracea family is one of the most important drugs used for the treatment of various diseases like Raktapitta (bleeding from various orifices), Shwasa (asthma), Kasa (dry and wet cough),Murccha (syncope), Kshaya(lean thin due to chronic illness), Abhighata (injury)(1), Shramahara (stress relieving), Pipasa (thirst), Jwara (fever)(2), Madyavikaranashaka(3) etc. Dates are very nutritious, expectorant, aphrodisiac, demulcent, laxative, diuretic. (4) As per the available data the $100 \mathrm{gm}$ fruit contain $277 \mathrm{Kcal}$ energy, $74.97 \mathrm{~g}$ carbohydrates, $1.81 \mathrm{~g}$ protein, $0.15 \mathrm{~g}$ Total fat, $6.7 \mathrm{~g}$ dietary fibers. The fruit is rich in dietary fiber, which prevents dietary LDL cholesterol absorption in the gut. It is also a good bulk laxative. The fibers content helps to protect the colon mucous membrane by decreasing exposure time and as well as binding to cancer causing chemicals in the colon.(5)

A large number of dates are grown in different places all over Globe especially in Punjab(India), Sindh, North Africa, Egypt and Syria with different names such as Pindkharjura, edible date, Dattel palm, Pindkhejur, Khurma, Chhuhara, Kharika, Khejur,

\section{*Corresponding Author:}

\section{Sujata P Dhoke}

Research Officer,

Regional Ayurveda Research institute for skin

disorders, Vijayawada-520015

Email: sujubasic@gmail.com
Khurmal yab, Perichchangayi etc. Dates are grown in Rohri of Sind Province having four varieties such as Lohar, Assuli, Thottiar, Idulshahi dates (6). Kharjura are of many varieties such as Khajoor, Pindakharjoor, Rajakharjoori, Madhukharjoori, Bhookharjoori and sulemanikharjoor (7). Number of varieties are available in market ranging from Rs. $45 /$ - per $1 \mathrm{~kg}$ to Rs. 850/- per $\mathrm{kg}$. Generally, customers are confused about the quality of Kharjura. Thus, after Survey in regional area, variety of Kharjura which was commonly used by the consumers was selected for the study and studied pharmacognostically to establish certain botanical standards for identification and standardization of three variety of Kharjura.

\section{Materials and Method}

For this study three varieties of fresh Kharjura samples were collected from the local market of Jamnagar, Gujarat, India and authenticated from Pharmacognosy laboratory, IPGT and RA, Jamnagar. The Organoleptic character as depicted in Table 1.

\section{Pharmacognostical studies of three samples:}

Free hand thin transverse sections of all sample fruits were taken for detailed microscopic observation. Morphological characters were studied by observing the fruit as such and also with the help of the dissecting microscope. Sections were observed as such for the presence of any crystals and then were stained with phloroglucinol and Conc. Hydrochloric acid $(\mathrm{HCl})$ to notice the lignified elements and other parts. 
Tables 1: Organoleptic Character of Three Samples

\begin{tabular}{|l|l|l|l|}
\hline Character & Yellow Kharjura Variety & Red Kharjura Variety & Dry Kharjura Variety \\
\hline Colour & Yellow & Red & Brown \\
\hline Odour & Not distinct & Not distinct & Sweetish \\
\hline Taste & Mild Sweet & Sweet & More sweet \\
\hline Touch & Smooth & Smooth & Rough \\
\hline Pulp & Fleshy & Fleshy & Absent \\
\hline
\end{tabular}

Tables 2: Histochemical evaluation of Three Kharjura Sample

\begin{tabular}{|l|l|l|l|l|l|l|}
\hline Sr. No & Reagent & To detect & Observation & Sample- 1 & Sample- 2 & Sample- 3 \\
\hline 1. & Phloroglucinol+Conc. HCl & Lignified cells & Red & ++ & ++ & ++ \\
\hline 2. & Iodine & Starch grains & Blue & ++ & ++ & ++ \\
\hline 3. & Phloroglucinol+Conc. $\mathrm{HCl}$ & $\begin{array}{l}\text { Calcium Oxa- } \\
\text { late }- \text { crystals }\end{array}$ & Dissolved & ++ & ++ & ++ \\
\hline 4. & $\mathrm{FeCl}_{3}$ solution & Tannin cells & Dark blue & ++ & ++ & ++ \\
\hline
\end{tabular}

$++=$ Present

Powder characters were studied according to the guidelines given as per Ayurvedic Pharmacopoeia of India. $(8,9)$ Sample thick sections subjected to histochemical tests to find out starch grains, tannin, calcium etc. by treating various reagents. (10)

\section{Results and Discussion}

Macroscopic examination of Sample-1(Yellow colored fresh fruit) shows fruit a drupe, oblong; 2 to 3 cm long, smooth, yellow colour, pulp fleshy, odour not distinct, taste mild sweet. The Organoleptic character as depicted in Table 1.

\section{Transverse section of Sample 1 \\ Transverse section of fresh Kharjura (yellow colored fresh fruit)}

Transverse section of fresh Kharjura showed outer epicarp followed by mesocarp and fibrousendocarp. Epicarp thick and hard made up of single layered epidermal cells with thick cuticle filled with suberine content. Mesocarp occupies wide range in the fruit differentiated in to upper tangentially, compactly arranged parenchymatous cells without any saccharin and tannin content. Inner mesocarp consist number of vascular bundles, they are open and collateral. Xylem made up of one or prominent structure with xylem fibers, phloem surrounds the xylem made of phloem fibers and sieve elements. Some of the mesocarp cells rarely contain silica deposition and oil globules.

Inner large rounded to oval shaped parenchyma cells with large amount of saccharine and tannin content. Beneath the epidermis at the zone of mesocarp compactly arranged two layered continuous ring of pitted stone cells with wide lumen. (Plate 1-from a to f).

Powder Microscopy of Sample-1 showed stone cells, vascular bundles, silica deposition, saccharine content, parenchyma cells with starch grains, group of stone cells.(Plate 2 from a to $f$ ).
Macroscopic examination of Sample 2 (Red colored fresh fruit) shows fruit a drupe, oblong; 2 to $3 \mathrm{~cm}$ long, smooth, red colour, pulp fleshy, odour not distinct, taste more sweet compare to Yellow Variety of Kharjura.

\section{Transverse section of Sample 2}

Diagrammatic transverse section of Phoenix Dactylifera Linn showed outer epicarp followed by mesocarp and fibrous endocarp. Epicarp thick and hard made up of single layered epidermal cells with thick cuticle filled with suberine content. Mesocarp occupies wide range in the fruit differentiated into upper tangentially compactly arranged parenchyma cells without any saccharin and tannin content. Inner large rounded to oval shaped parenchyma cells with large amount of saccharine and tannin content. Beneath the epidermis at the zone of mesocarp compactly arranged one-two layered smaller similar stone cells forming ring than leads to two-three layered continuous ring of large uneven shaped pitted stone cells with wide lumen. Inner mesocarp consist number of vascular bundles, they are open and collateral. Xylem made up of one or prominent structure with xylem fibers, phloem surrounds the xylem made of phloem fibers and sieve elements. Some of the mesocarp cells rarely contain silica deposition and oil globules. (Plate 2 from a to $\mathrm{f}$ )

Macroscopic examination of Sample 3 (Dry kharjura fruit) was observed that a drupe, oblong, 2 to $3 \mathrm{~cm}$ long, smooth, brownish colour, dry in touch, sweetish odour with sweet taste.

\section{Transverse section of Sample 3}

It showed outer epicarp followed by mesocarp and fibrous endocarp. Epicarp thick and hard made up of single layered epidermal cells with thick cuticle filled with suberine content. Mesocarp occupies wide range in the fruit differentiated in to upper tangentially compactly arranged parenchyma cells without any saccharin and tannin content. Inner large rounded to 
oval shaped parenchyma cells with large amount of saccharine and tannin content.

Xylem made up of one or prominent structure with xylem fibers, phloem surrounds the xylem made of phloem fibers and sieve elements. Beneath the epidermis at the zone of mesocarp compactly arranged two-three layered continuous ring of large uneven shaped, pitted stone cells with wide lumen. Inner mesocarp consist number of vascular bundles, they are open and collateral. Some of the mesocarp cells rarely contain silica deposition and oil globules. (Plate 4 from a to f)

Powder Microscopy of Sample 3 Showed the powder stone cells, fibers, silica deposition, blunted fibers, starch grains and lignified pitted fibers.(Plate 5 from a to $h)$.

\section{Discussion}

Available in two colour i.e. The fresh Kharjura showed yellow and red colour while the dry Kharjura showed dark brown colour. Both the varieties were sweet in taste but Red variety seen more sweet compare to Yellow variety Kharjura. The fresh Kharjura does not have characteristic smell, but dryKharjura with sweet odour.

In Yellow and Red variety Kharjura, mesocarp occupies wide space in the fruit differentiated in to upper tangentially compactly arranged parenchyma cells without any saccharin and tannin content, while in dry Kharjura saccharin and tannin contents were found. In Yellow and Red variety Kharjura pitted stone cells with wide lumen were found arranged in two layers. While in dry Kharjura, pitted stone cells with narrow lumen were found which arranged in two-three layers. Vascular bundles were found open and collateral in all the three varieties.

The squashed Yellow and Red variety Kharjurashowed stone cells, fragment of endocarp, lignified fibers and fragments of trachieds, which were not seen in the dryKharjura. The squashed dryKharjurashowed epicarp cells, saccharine content, acicular crystals and spiral vessel, which were absent in the fresh samples.Both the samples showed similar squashed characters like tannin content, mesocarp cells, annular vessels,epicarp cells, saccharine content, lignified stone cells, etc.

Histochemical evaluation showed that similar observation but in dried Kharjura lignified material is more as compared to Yellow and Red variety sample.

\section{Conclusion}

Pharmacodynamics and pharmacokinetics of the drugs depends on its Panchabhautika (five elements of universe) conjugation and configuration. Here conjugation means joining or union or mixing. Configuration means the relative arrangement or placement of basic constituents of the substances. Developing oneself with this concept will make the fundamentals very clear and strong.

To understand the concept of origin of drugs as a whole, one has to go to its base which is understood with this Panchmahabhuta. Pharmacognostical evaluation revealed differentiation between dry Kharjura and fresh
Kharjura. Fresh Kharjura contains more watersoluble content and loosely arranged parenchyama cells. It has more JalaMahabhuta dominancy according to Ayurveda concept. So, in conditions of instant nourishment fresh Kharjura variety will gives more result compare to Dry Kharjura. Similarly, Dry Varierty of Kharjura shows packed mesenchyamal cells and silica deposition and stone cells which showed Prithvi Mahabhuta dominancy, So where long lasting stability is required then Dry Variety of Kharjura will be used.

\section{Reference}

1. Bhavaprakasha, Shree Bhavamishra, VidyodinihindiCommentary, Shree Bhrahmashankara Mishra and RupalalajiVaishya,Aamradi

Varga ChaukhambaSanskritaBhawan Varanasi,2010, p.135.

2. Charaka Samhita, Agnivesha, Ayurvedadipika Sanskrit commentary , Vaidya YadavajiTrikamaji, Chikitsasthana, jwarachikitsaadhyaya (3: 237), ,Chaukhambha Sanskrita Sansthana Prakashana, Varanasi, 2011, p.420.

3. Sharangadhara Samhita, PanditaSharangadharacharya with Dipika Hindi Commentary ,Dr. BhrahmanandTripathi, Twitiya Khanda, Phantanirmanavidhi ,Choukhamba SurabharatiPrakashana, Varanasi,2010, p.163.

4. Indian MatericaMedica, by Prof.K.M.Nadakarni, revised and enlarged by A.K.Nadakarani, Vol-I, Popular Prakashana,Mumbai, PVT.LMT.,1976, p.944.

5. Dates (Phoenix dactylifera), Medjool, Nutritive Value per 100 g (Source: USDA National Nutrient data base). Retrieved from http:// p.b5z.net/i/u/6068813/f/healthbenefitsofdates.pdf [Accessed on: 23/01/17]

6. Indian Materica Medica, by Prof.K .M .Nadakarni, revised and enlarged by A.K.Nadakarani, Vol-I, Popular Prakashana, Mumbai, PVT.LMT,1976,p.946.

7. The Ayurvedic Plants by Prof.P.H.Kulkarni and Dr.Shalini Ansari Indian medical Science series no.132 Sri Satguru Publications A division of Indian books centre Delhi, India,p. 240.

8. Krishnamurty K.V,Methods in Plant Histochemistry. Vishwanadhanpvt. Limted, Madras, 1988, pg. 1-77.

9. Anonymous: The Ayurvdic Pharmacopoeia of India, Part-I, Vol.-IV, Govt. of India, Ministry of Health and Family Welfare, Department of I.S.M. \& H, New Delhi; 1st edition 1999. Appendix 2

10. The Ayurvedic Pharmacopeia of India PDF 1, Vol 4 Delhi: Ministry of health \& Family welfare department of Ayush; 2007, p. 52. 
Plates 1:T.S. of Sample 1
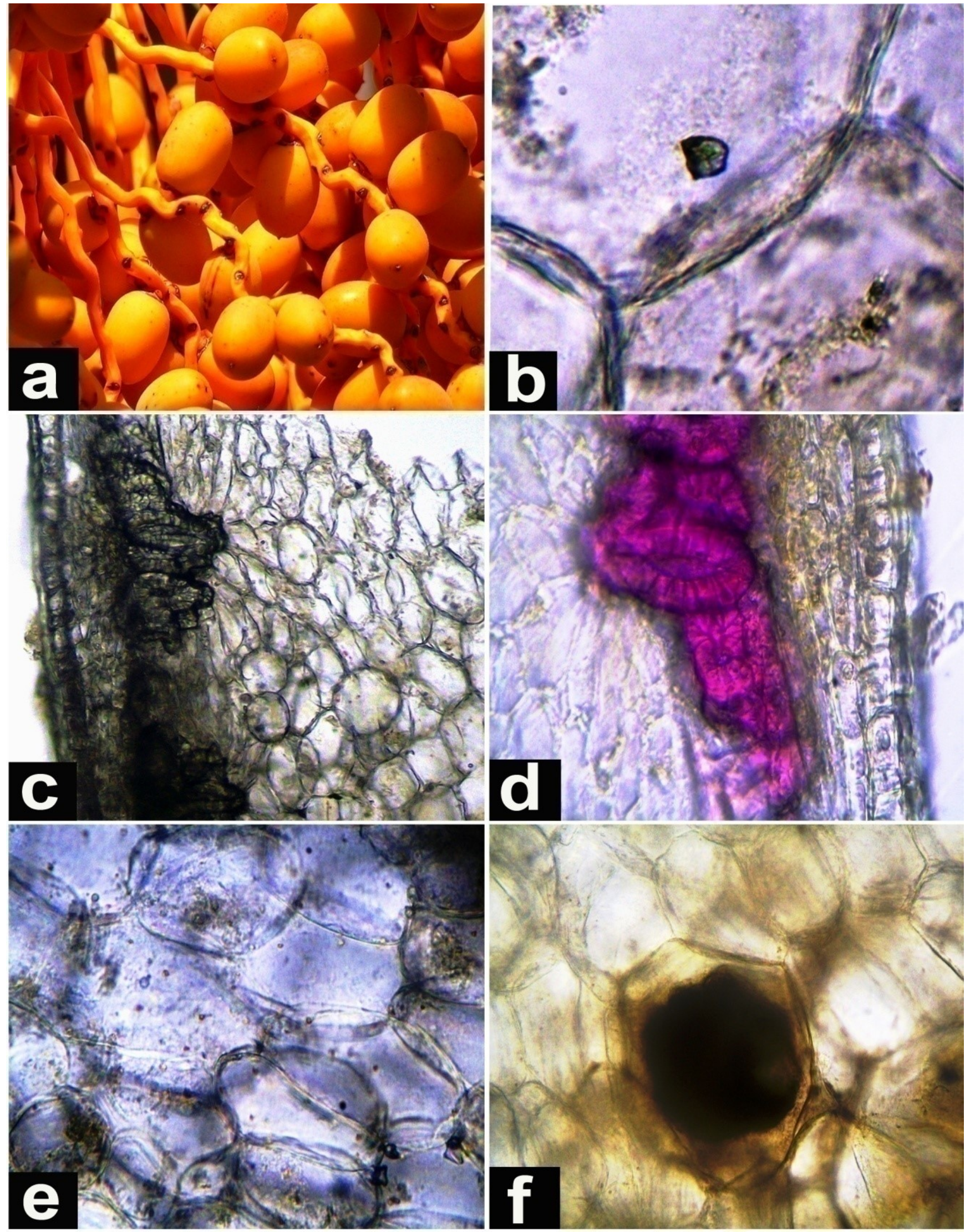

Plate 1-[a-Yellow Kharjura Fruit, b-Crystalline Material, c-Epidermis Hypodermis Layer, d-Lignified stone cell layer, 
Plate 2: Powder microscopy of Sample 1
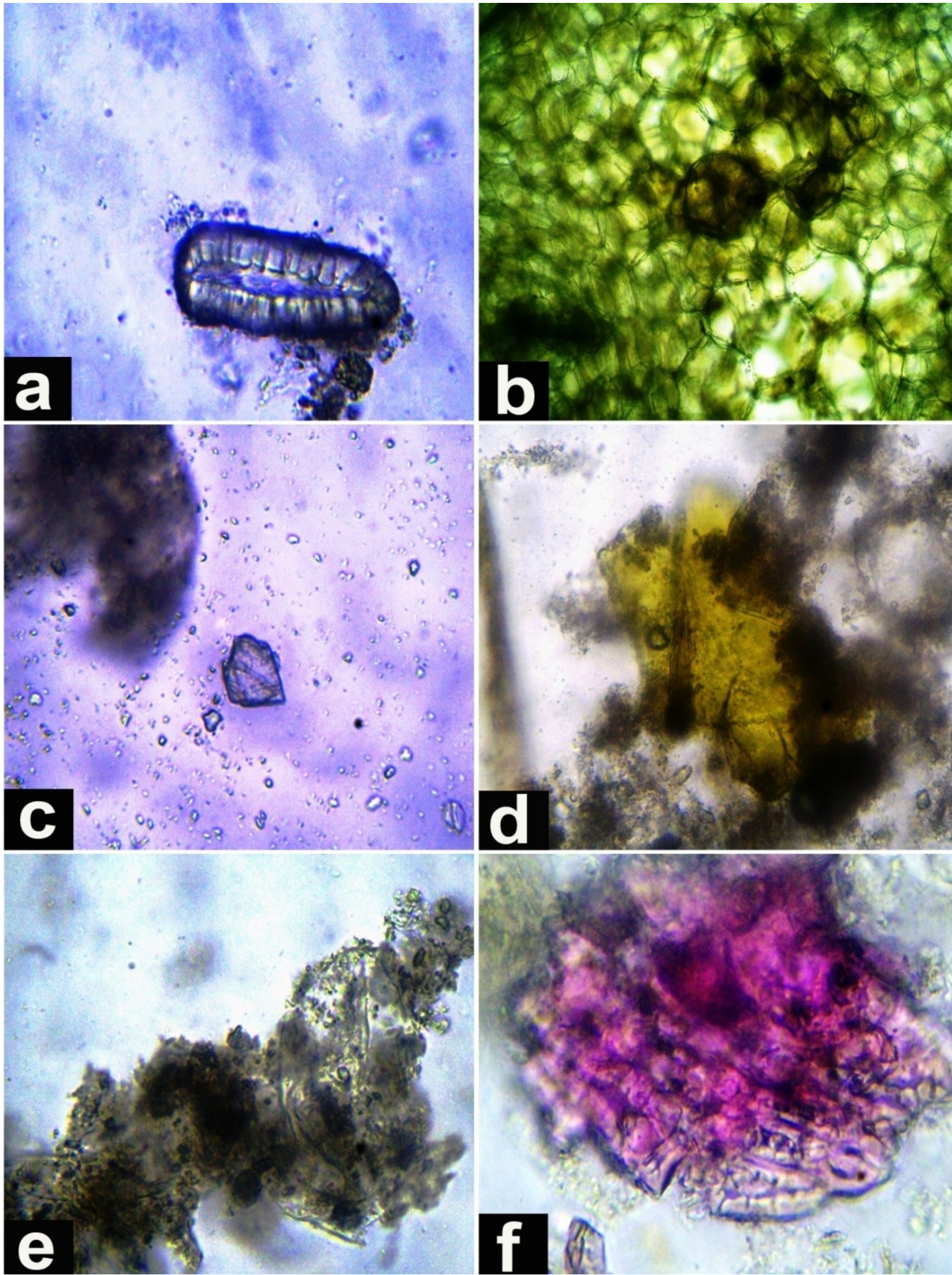

Plate 2-[a-Stone cells, b-Vascular Bundles, c-Silica deposition, d-Saccarine content, e-Parenchymal cell with starch grains, f-Group of stone cells ] 
Plates 3: T.S. of Sample 2


Plate 3-[a-Red Kharjura Fruit, b-1-2 layer stone cells, c-Epicarp Mesocap Layer, d-Multilayer loosely arranged parenchyama, e- Saccharine content, f-Single layer epidermis ] 
Plates 4: T.S. of Sample 3


Plate 4 -[a-Dry Kharjura Fruit, b-Compact arranged Mesocarp Cells, c-Epicarp Mesocarp Endocarp,dMultilayer epicarp with stone cells, e- Vascular bundles with stone cells, f-Lignified stone cells ] 
Plates 5: Powder microscopy of Sample 3
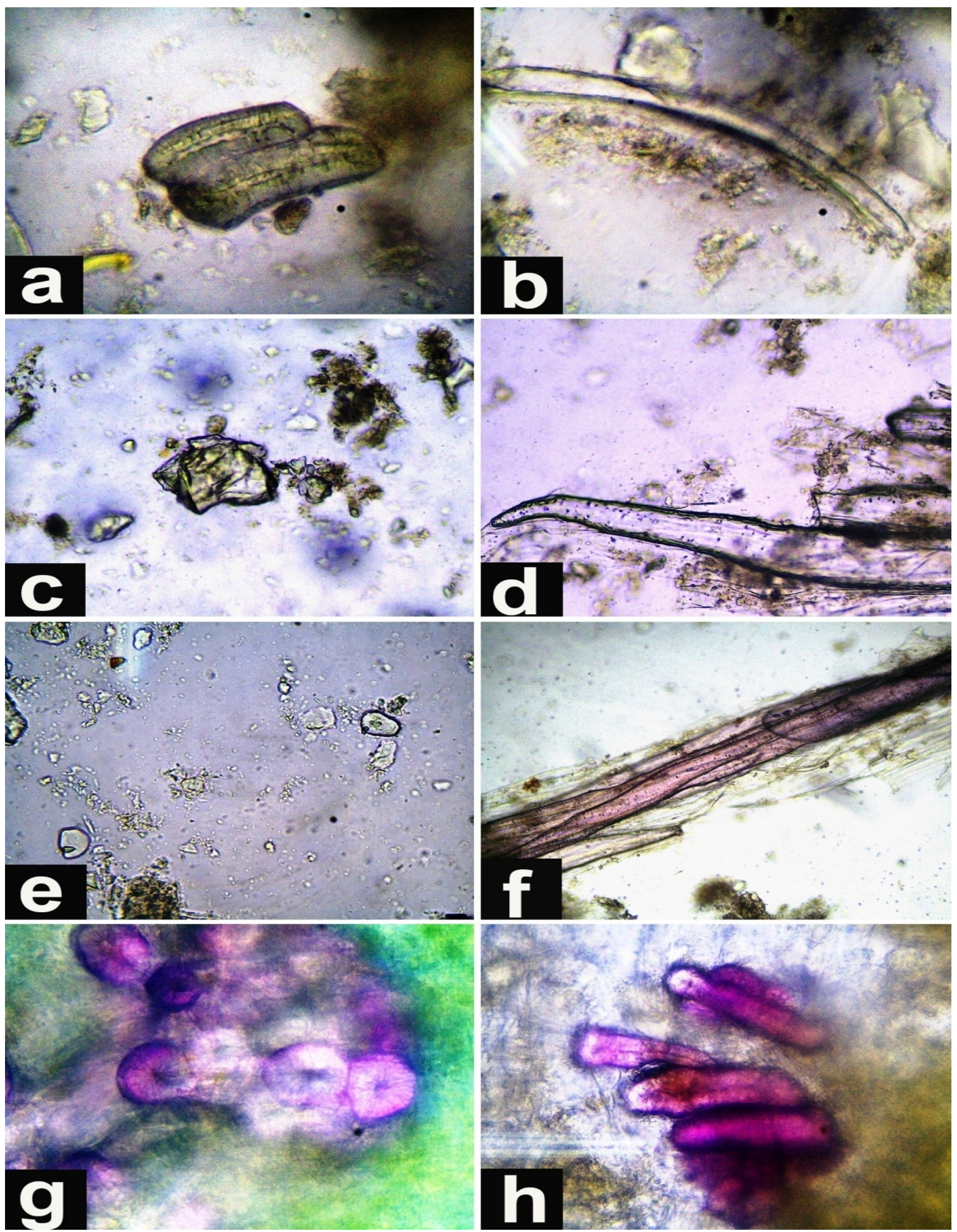

Plate 5-[a-Powder stone cells, b-Fibres, c-Silica deposition, d-Blunted fibers, e-Starch grains, f-Lignified Pitted fibres, g-Group of stone cells, h-Group of stone cells] 